\title{
Ureter Lymphoma
}

National Cancer Institute

\section{Source}

National Cancer Institute. Ureter Lymphoma. NCI Thesaurus. Code C6175.

A lymphoma involving the ureter. 